\title{
Candida laoshanensis sp. nov. and Candida qingdaonensis sp. nov., anamorphic, ascomycetous yeast species isolated from decayed wood
}

Correspondence

Fu-Li Li

lifl@qibebt.ac.cn
Shi-An Wang, ${ }^{1}$ Fu-Li Li ${ }^{1}$ and Feng-Yan Bai ${ }^{2}$

${ }^{1}$ Key Laboratory of Biofuels, Qingdao Institute of BioEnergy and Bioprocess Technology, Chinese
Academy of Sciences, Qingdao 266101, PR China
${ }^{2}$ Systematic Mycology and Lichenology Laboratory, Institute of Microbiology, Chinese Academy of
Sciences, Beijing 100101, PR China

During a study of newly isolated yeast strains utilizing D-xylose as sole carbon source, eight strains, isolated from decayed wood, were found to represent two novel anamorphic, ascomycetous yeast species based on sequence analysis of the 26S rDNA D1/D2 domain and internal transcribed spacer region, and phenotypic characterization. The names Candida laoshanensis sp. nov. (type strain MLRW 6-2 ${ }^{\top}=A S 2.4030^{\top}=\mathrm{CBS} 11389^{\top}$ ) and Candida qingdaonensis sp. nov. (type strain MLRW $7-1^{\top}=$ AS $2.4031^{\top}=$ CBS $11390^{\top}$ ) are proposed for these two novel species; the closest relatives of the two novel species are Candida pomicola and Candida marilandica, respectively.
D-Xylose constitutes $10-40 \%$ of the total carbohydrate of lignocellulose (Ladisch et al., 1983) and, therefore, complete utilization of the sugar is important economically for bioethanol production by yeasts. However, only a limited number of yeast species have been found that convert D-xylose to ethanol (Barnett et al., 2000; HahnHägerdal et al., 2007). Nevertheless, many novel yeast species, including xylose-fermenting taxa, have been discovered in beetle gut in recent years and it is believed that nature might reveal many more yeasts with unusual capacities for xylose, xylan and lignin degradation (Suh et al., 2003, 2004, 2005). As part of studies aimed at exploring xylose-fermenting yeasts from nature, yeasts were isolated from the gut of insects, decayed wood and leaves of plants in Lao Mountain, Shandong Province, East China, in Autumn 2008. Strains able to utilize D-xylose as the sole carbon source were first enriched and isolated; fermentation tests were then performed. Among the strains able to grow on D-xylose but not ferment it, eight were found to represent two novel species based on sequence analysis of the $26 \mathrm{~S} \mathrm{rDNA}$ D1/D2 domain and internal transcribed spacer (ITS) region. Complete descriptions of the two species are given in this report.

Yeast strains inhabiting the decayed wood were isolated by using an enrichment method. Pieces of decayed wood were

Abbreviation: ITS, internal transcribed spacer.

The GenBank/EMBL/DDBJ accession numbers for the ITS region and 26S rDNA D1/D2 domain sequences of strain MLRW 6-2 ${ }^{\top}$ are FJ613523 and FJ613526, respectively, and those for strain MLRW $7-1^{\top}$ are FJ613524 and FJ613527, respectively. placed into yeast minimal medium (YMM) broth containing yeast nitrogen base without amino acids $\left(6.7 \mathrm{~g} \mathrm{l}^{-1}\right.$; Difco), $2 \%(\mathrm{w} / \mathrm{v})$ D-xylose, $0.5 \%(\mathrm{w} / \mathrm{v})\left(\mathrm{NH}_{4}\right)_{2} \mathrm{SO}_{4}$ and $200 \mu \mathrm{g}$ chloramphenicol $\mathrm{ml}^{-1}$. After cultivation for 714 days, aliquots $(100 \mu \mathrm{l})$ of $10^{-1}-10^{-4}$ diluted cultures were spread on YMM agar plates. After incubation for 2 days at room temperature (about $25{ }^{\circ} \mathrm{C}$ ), colonies with different morphological characters were transferred to YPX slants, which contained $0.3 \%(\mathrm{w} / \mathrm{v})$ yeast extract, $0.5 \%$ $(\mathrm{w} / \mathrm{v})$ peptone, $2 \%(\mathrm{w} / \mathrm{v})$ D-xylose and $2 \%(\mathrm{w} / \mathrm{v})$ agar, for further purification and examination.

Morphological, physiological and biochemical characteristics were examined according to the standard methods commonly used in yeast taxonomy (Yarrow, 1998). Assimilation of nitrogen compounds was investigated on solid media with starved inocula (Nakase \& Suzuki, 1986).

Nuclear DNA was extracted by the method of Makimura et al. (1994). The large-subunit rDNA D1/D2 domain was amplified by using primer pairs NL1 (5'-GCATATCGGTAAGCGGAGGAAAAG- $3^{\prime}$ ) and NL4 (5'-GGTCCGTGTTTCAAGACGG- $3^{\prime}$ ). The DNA fragment covering the ITS region (including 5.8S rDNA) was amplified by using primers ITS1 (5'-GTCGTAACAAGGTTTCCGTAGGTG$\left.3^{\prime}\right)$ and ITS4 (5'-TCCTCCGCTTATTGATATGC- $\left.3^{\prime}\right)$. The amplification conditions for the two DNA domains were: 4 min initial denaturation at $94{ }^{\circ} \mathrm{C}, 30$ cycles each of $30 \mathrm{~s}$ at $94{ }^{\circ} \mathrm{C}, 1 \mathrm{~min}$ at $52{ }^{\circ} \mathrm{C}$ and $1 \mathrm{~min}$ at $72{ }^{\circ} \mathrm{C}$, and a final extension period of $8 \mathrm{~min}$ at $72{ }^{\circ} \mathrm{C}$. Molecular phylogenetic analysis was performed by the methods described by Bai et al. (2002). Reference sequences were retrieved from GenBank (accession numbers are indicated in Fig. 1). 


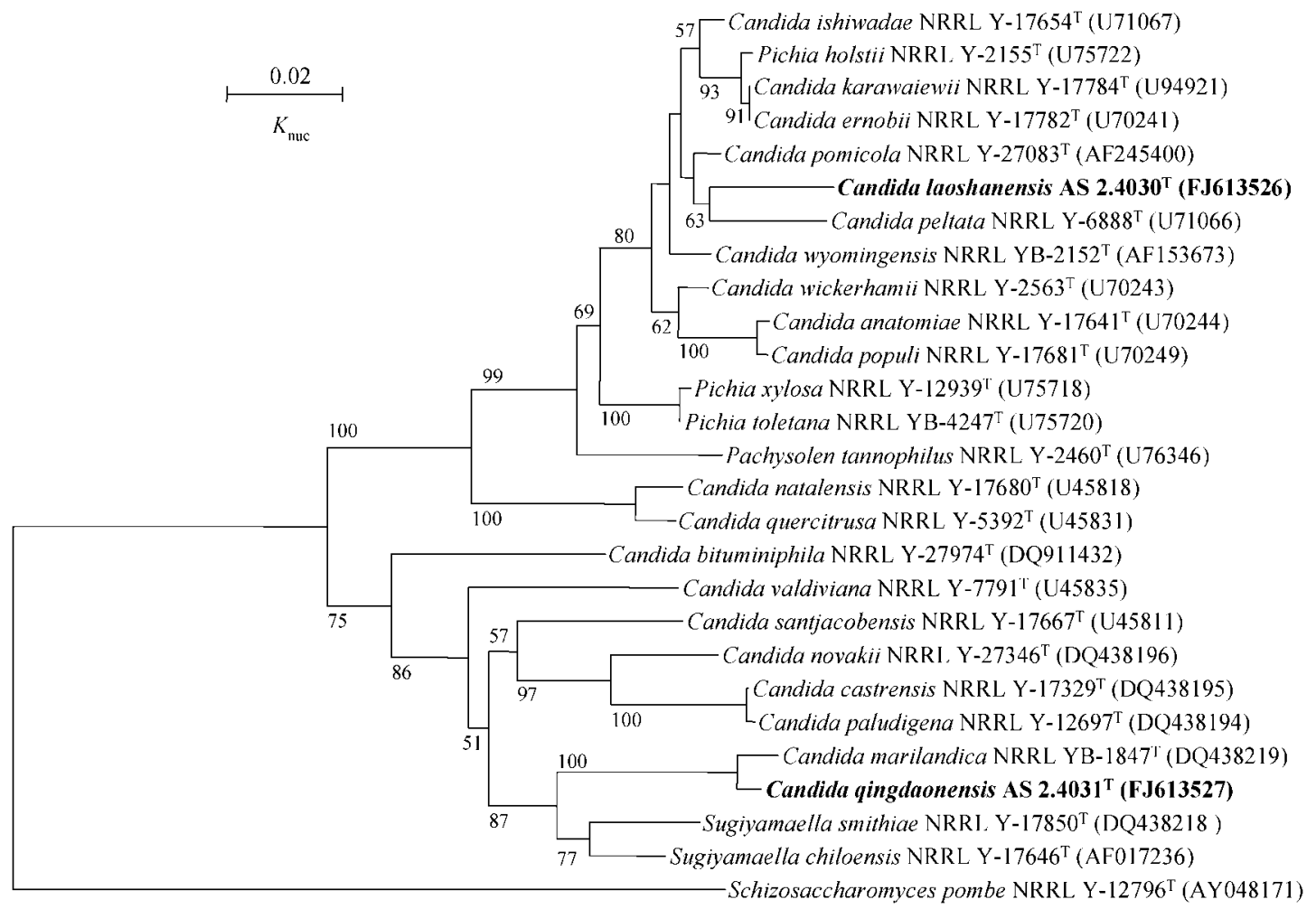

Fig. 1. Phylogenetic tree drawn from neighbour-joining analysis of the $26 \mathrm{~S}$ rDNA D1/D2 domain, depicting the relationships of the two novel species with closely related taxa. Bootstrap values (\%) over $50 \%$ from 1000 bootstrap replicates are shown. Reference sequences were retrieved from GenBank under the accession numbers indicated.

Two groups of four strains (MLRW 6-1, MLRW 6-2 ${ }^{\mathrm{T}}$, MLRW 6-3 and MLRW 6-4; and MLRW 7-1 ${ }^{\mathrm{T}}$, MLRW 7-2, MLRW 7-3 and MLRW 7-4) were recognized. Members of each group had identical D1/D2 domain and ITS sequences, but characteristics of the two groups differed from one another indicating that the strains in each of the two groups were conspecific. MLRW 6-2 ${ }^{\mathrm{T}}$ and MLRW 7-1 ${ }^{\mathrm{T}}$ were selected as representatives of the two groups for further comparison. The sizes of the D1/D2 domains of strains MLRW 6-2 ${ }^{\mathrm{T}}$ and MLRW $7-1^{\mathrm{T}}$ were determined as 532 and $530 \mathrm{bp}$, respectively. The phylogenetic positions of the two strains are depicted in the tree constructed from D1/D2 sequences (Fig. 1). Strain MLRW 6-2 ${ }^{\mathrm{T}}$ differed from the type strains of the closely related species Candida pomicola and Candida peltata by $15(2.8 \%)$ and $22(4.1 \%)$ substitutions in the D1/D2 domain, respectively. Strain MLRW $7-1^{\mathrm{T}}$ was closely related to the type strain of Candida marilandica; these two strains differed by 6 (1.1\%) substitutions in the D1/D2 domain. MLRW 7-1 ${ }^{\mathrm{T}}$ differed from the type strains of its close relatives Sugiyamaella chiloensis and Sugiyamaella smithiae by more than 30 substitutions $(>5 \%)$ in the D1/D2 domain. According to previous studies, yeast strains that show nucleotide substitutions greater than $1 \%$ in the D1/D2 domain are likely to represent different species (Fell et al., 2000; Kurtzman \& Robnett, 1998).
The distinction of the two species from their close relatives was further supported by ITS sequence comparison. Strain MLRW $6-2^{\mathrm{T}}$ differed from the type strains of both $C$. pomicola and C. peltata by more than $15 \%$ mismatches in the ITS region. Although strain MLRW $7-1^{\mathrm{T}}$ and the type strain of C. marilandica differed by only $1.1 \%$ in the D1/ D2 domain, they showed $10.6 \%$ mismatches (49 substitutions and 10 gaps) in the ITS region; all other related strains differed from MLRW $7-1^{\mathrm{T}}$ by more than $15 \%$ mismatches in the ITS region.

Strains MLRW 6-1 and MLRW 6-2 ${ }^{\mathrm{T}}$ and strains MLRW 63 and MLRW 6-4 were isolated from two different pieces of an unidentified decayed wood block, respectively. Strains MLRW 7-1 ${ }^{\mathrm{T}}$ and MLRW 7-2 and strains MLRW 7-3 and MLRW 7-4 were isolated from two different pieces of a decayed wood block of Pinus tabulaeformis Carr., respectively. Within each group, all four strains exhibited similar morphological and physiological characters. In addition to sequence data, phenotypic characters could also be used to differentiate them from closely related taxa, especially in assimilation reactions of carbon compounds (Table 1). For clearer comparisons of close relatives, the species compared were classified into two groups based on their phylogenetic relationships (Fig. 1). Sporulation tests were done in all eight strains, but sexual states were not observed on the sporulation media of Wang et al. (2008). Also, mating 
Table 1. Physiological characteristics that differentiate the two novel species from closely related taxa

Species: 1, C. laoshanensis sp. nov. (this study); 2, C. pomicola (Kurtzman et al., 2001); 3, C. peltata (Barnett et al., 2000); 4, C. qingdaonensis sp. nov. (this study); 5, C. marilandica (Kurtzman, 2007). Abbreviations: +, positive; -, negative; $D$, delayed positive; $\mathrm{W}$, weak; S, slow; V, variable; and NT, not tested. Results that differ between strains of the same species are shown (separated by solidi).

\begin{tabular}{|c|c|c|c|c|c|}
\hline \multirow[t]{2}{*}{ Characteristic } & \multicolumn{3}{|c|}{ Group I } & \multicolumn{2}{|c|}{ Group II } \\
\hline & 1 & 2 & 3 & 4 & 5 \\
\hline \multicolumn{6}{|l|}{ Fermentation of: } \\
\hline Glucose & + & + & + & $\mathrm{W}$ & - \\
\hline Galactose & + & - & D & - & - \\
\hline \multicolumn{6}{|l|}{ Assimilation of: } \\
\hline L-Sorbose & - & $\mathrm{v}$ & + & + & + \\
\hline Melezitose & D & + & + & + & + \\
\hline D-Ribose & + & + & + & $-1+$ & + \\
\hline L-Rhamnose & + & + & + & $\mathrm{D}$ & - \\
\hline D-Glucosamine & $+/ \mathrm{D}$ & $+/ \mathrm{D}$ & $\mathrm{D} /-$ & + & + \\
\hline Ethanol & + & + & $+1-$ & $-1+$ & + \\
\hline Erythritol & - & $+/ \mathrm{w}$ & $+/ \mathrm{D}$ & + & + \\
\hline Galactitol & $\mathrm{w} /-$ & - & $+/ \mathrm{D}$ & $\mathrm{D} /+$ & - \\
\hline Methyl $\alpha$-D-glucoside & $\mathrm{D}$ & $+/ \mathrm{D}$ & + & + & + \\
\hline DL-Lactic acid & + & - & $+1-$ & - & - \\
\hline Succinic acid & $+/ \mathrm{D}$ & + & + & $+/ \mathrm{w} / \mathrm{s}$ & - \\
\hline Nitrate & - & + & - & + & + \\
\hline Nitrite & - & + & - & + & NT \\
\hline
\end{tabular}

types were not found in mating tests between the isolates in each group.

The molecular and phenotypic data showed that strains MLRW 6-2 ${ }^{\mathrm{T}}$ and MLRW $7-1^{\mathrm{T}}$ represent two novel anamorphic, ascomycetous yeast species. According to the current taxonomy of ascomycetous yeasts (Kurtzman, 1998; Meyer et al., 1998), the two species could only be assigned to the anamorphic genus Candida. The names Candida laoshanensis sp. nov. (type strain MLRW 6-2 $2^{\mathrm{T}}$ ) and Candida qingdaonensis sp. nov. (type strain MLRW 7$1^{\mathrm{T}}$ ) are proposed.

In a previous study, more than $70 \%$ of the 670 described yeast species were capable of utilizing D-xylose, but only approximately $1 \%$ of them were able to ferment the sugar (Barnett et al., 2000; Hahn-Hägerdal et al., 2007). Among the xylose-fermenting yeast species, Pichia stipitis, Pichia segobiensis, Candida shehatae and Enteroramus dimorphus clustered in a well-supported clade in the phylogenetic tree constructed from combined LSU and SSU rDNA sequence data, whereas the other five species were located in different clades (Suh et al., 2003, 2004). In our present study, no yeast strains capable of fermenting D-xylose were found among 120 newly isolated xylose-utilizing strains and Pachysolen tannophilus is the only xylose-fermenting species among the taxa in the presented phylogenetic tree
(Fig. 1). This implies the rarity of xylose-fermenting yeast species as indicated in previous publications.

\section{Latin diagnosis of Candida laoshanensis Li et Wang sp. nov.}

In medio liquido $\mathrm{YM}$ post 3 dies ad $25{ }^{\circ} \mathrm{C}$, cellulae ellipsoideae, $2.0-5.0 \times 2.5-6.5 \mu \mathrm{m}$, cellulae singulae, binae et adhaerentes. Per gemmationem multipolarem reproducentes. Post 1 mensem sedimentum formatur. In agaro YM post 1 mensem ad $25{ }^{\circ} \mathrm{C}$, candida vel cremea, glabra. In agaro farinae Zea mays post 7 dies, pseudohyphae eumorphum. Ascomata nulla. Glucosum et galactosum fermentantur at non sucrosum, maltosum, raffinosum, lactosum nec Dxylosum. Glucosum, galactosum, sucrosum, maltosum, cellobiosum, trehalosum, melezitosum (lente), amylum solubile, D-xylosum, L-arabinosum (varium), D-arabinosum (varium), D-ribosum, L-rhamnosum, D-glucosaminum (varium), ethanolum, glycerolum, ribitolum, galactitolum (varium), $D$ mannitolum, D-glucitolum, methyl $\alpha$-D-glucosidum (lente), salicinum, DL-lacticum, acidum succinicum (varium) et acidum citricum assimilantur at non L-sorbosum, lactosum, melibiosum, raffinosum, inulinum, methanolum, erythritolum nec inositolum. Ammonium sulfatum, ethylaminum, cadaverinum et L-lysinum assimilantur at non kalium nitricum nec natrum nitrosum. Ad crescentiam vitaminum non necessarium est. Augmentum in $37^{\circ} \mathrm{C}$, at non $40{ }^{\circ} \mathrm{C}$. Materia amyloidea iodophila non formantur. Diazonium caeruleum B non respondens. Ureum non hydrolysatur. Typus depositus in collectione China General Microbiological Culture Collection Center, Academia Sinica $\left(\right.$ AS $2.4030^{\mathrm{T}}$ ).

\section{Description of Candida laoshanensis Li \& Wang sp. nov.}

Candida laoshanensis (lao.shan.en'sis. N.L. fem. adj. laoshanensis of Lao mountain, referring to the geographical origin of the type strain).

In YM broth, after 3 days at $25{ }^{\circ} \mathrm{C}$, cells are ellipsoidal, 2.0$5.0 \times 2.5-6.5 \mu \mathrm{m}$, and occur singly, in pairs or in groups (Fig. 2a). Budding is multilateral. After 1 month at $25^{\circ} \mathrm{C}$, sediment is present. After 1 month on YM agar at $25^{\circ} \mathrm{C}$, the streak culture is white to cream and smooth with an entire margin. Pseudohyphae are not formed in Dalmau plate cultures on corn-meal agar after 7 days at $25{ }^{\circ} \mathrm{C}$. Ascospores are not formed. Glucose and galactose are fermented; sucrose, maltose, raffinose, lactose and xylose are not fermented. Glucose, galactose, sucrose, maltose, cellobiose, trehalose, melezitose (delayed), soluble starch, D-xylose, L-arabinose (variable), D-arabinose (variable), Dribose, L-rhamnose, D-glucosamine (variable), ethanol, glycerol, ribitol, galactitol (variable), D-mannitol, D-glucitol, methyl $\alpha$-D-glucoside (delayed), salicin, DL-lactic acid, succinic acid (variable) and citric acid are assimilated; Lsorbose, lactose, melibiose, raffinose, inulin, methanol, erythritol and inositol are not assimilated. Ammonium sulfate, ethylamine hydrochloride, cadaverine hydrochloride 

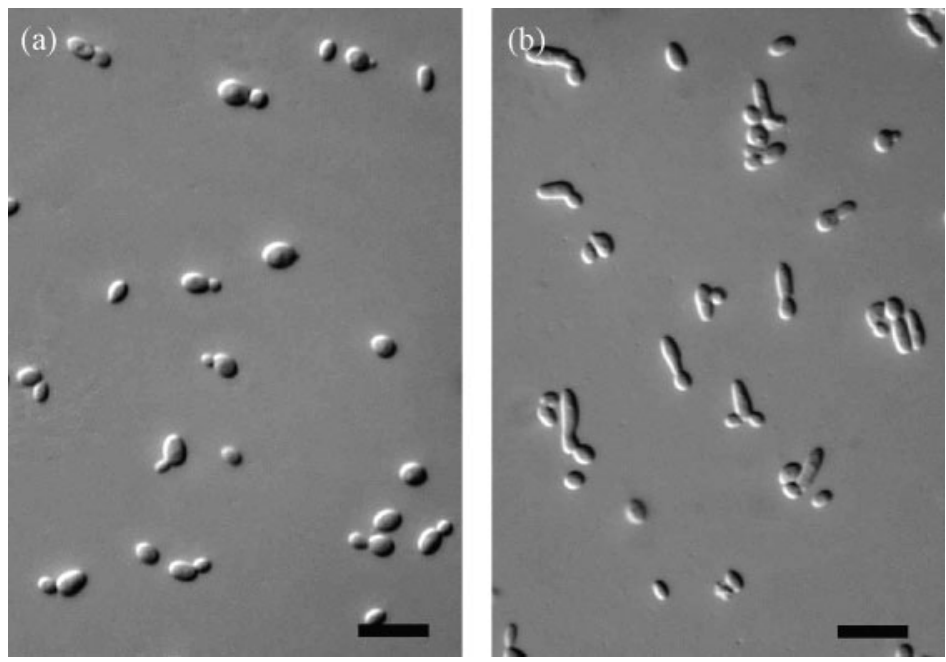

Fig. 2. Budding cells of Candida laoshanensis sp. nov. MLRW 6-2 ${ }^{\top}$ (a) and Candida qingdaonensis sp. nov. MLRW 7-1 ${ }^{\top}$ (b) grown in YM broth for 2 days at $25^{\circ} \mathrm{C}$. Bars, $10 \mu \mathrm{m}$.

and L-lysine are assimilated; potassium nitrate and sodium nitrite are not assimilated. Growth in vitamin-free medium is negative. Growth at $37{ }^{\circ} \mathrm{C}$ is positive; growth at $40{ }^{\circ} \mathrm{C}$ is negative. Starch-like compounds are not produced. Diazonium blue B reaction is negative. Urease activity is negative.

The type strain is MLRW $6-2^{\mathrm{T}} \quad\left(=\mathrm{AS} \quad 2.4030^{\mathrm{T}}=\mathrm{CBS}\right.$ $11389^{\mathrm{T}}$ ), isolated from a piece of decayed wood from Lao Mountain in Shandong Province in the east of China in September 2008.

\section{Latin diagnosis of Candida qingdaonensis Li et Wang sp. nov.}

In medio liquido $\mathrm{YM}$ post 3 dies ad $25{ }^{\circ} \mathrm{C}$, cellulae ellipsoideae vel elongatae, $2.0-4.0 \times 3.5-10.0 \mu \mathrm{m}$, cellulae singulae, binae et adhaerentes. Per gemmationem multipolarem reproducentes. Post 1 mensem sedimentum formatur. In agaro YM post 1 mensem ad $25{ }^{\circ} \mathrm{C}$, candida vel cremea, glabra, margo glabro. In agaro farinae Zea mays post 7 dies, pseudohyphae et hyphae eumorphum. Ascomata nulla. Glucosum (infirme) fermentantur at non galactosum, sucrosum, maltosum, raffinosum, lactosum nec D-xylosum. Glucosum, galactosum, L-sorbosum, sucrosum, maltosum, cellobiosum, trehalosum, melibiosum, raffinosum, melezitosum, inulinum (varium), D-xylosum, L-arabinosum, Darabinosum, D-ribosum (varium), L-rhamnosum (lente), Dglucosaminum, ethanolum (varium), erythritolum, ribitolum, galactitolum (lente), D-mannitolum, D-glucitolum, methyl $\alpha$-D-glucosidum, salicinum, acidum succinicum (varium) et inositolum assimilantur at non lactosum, amylum solubile, methanolum, glycerolum, DL-lacticum nec acidum citricum. Ammonium sulfatum, ethylaminum, cadaverinum, L-lysinum, kalium nitricum et natrum nitrosum assimilantur. Ad crescentiam vitaminae externae necessariae sunt. Augmentum in $37^{\circ} \mathrm{C}$, at non $40{ }^{\circ} \mathrm{C}$. Materia amyloidea iodophila non formantur. Diazonium caeruleum B non respondens. Ureum non hydrolysatur. Typus depositus in collectione China General Microbiological Culture Collection Center, Academia Sinica (AS 2.4031 ${ }^{\mathrm{T}}$ ).

\section{Description of Candida qingdaonensis Li \& Wang sp. nov.}

Candida qingdaonensis (qing.dao.nen'sis. N.L. fem. adj. qingdaonensis of Qingdao, referring to the geographical origin of the type strain).

In YM broth, after 3 days at $25{ }^{\circ} \mathrm{C}$, cells are ellipsoidal to elongate, $2.0-4.0 \times 3.5-10.0 \mu \mathrm{m}$, and occur singly, in pairs or in groups (Fig. 2b). Budding is multilateral. After 1 month at $25{ }^{\circ} \mathrm{C}$, sediment is present. After 1 month on YM agar at $25{ }^{\circ} \mathrm{C}$, the streak culture is white to cream, smooth and somewhat dull, with an entire margin. Neither pseudohyphae nor true hyphae are formed in Dalmau plate cultures on corn-meal agar after 7 days at $25^{\circ} \mathrm{C}$. Ascospores are not formed. Glucose (weak and slow) is fermented; galactose, sucrose, maltose, raffinose, lactose and xylose are not fermented. Glucose, galactose, Lsorbose, sucrose, maltose, cellobiose, trehalose, melibiose, raffinose, melezitose, inulin (variable), D-xylose, L-arabinose, D-arabinose, D-ribose (variable), L-rhamnose (delayed), D-glucosamine, ethanol (variable), erythritol, ribitol, galactitol (delayed), D-mannitol, D-glucitol, methyl $\alpha$-D-glucoside, salicin, succinic acid (variable) and inositol are assimilated; lactose, soluble starch, methanol, glycerol, DL-lactic acid and citric acid are not assimilated. Ammonium sulfate, ethylamine hydrochloride, cadaverine hydrochloride, L-lysine, potassium nitrate and sodium nitrite are assimilated. Growth in vitamin-free medium is positive. Growth at $37{ }^{\circ} \mathrm{C}$ is positive; growth at $40{ }^{\circ} \mathrm{C}$ is negative. Starch-like compounds are not produced. Diazonium blue $\mathrm{B}$ reaction is negative. Urease activity is negative.

The type strain is MLRW $7-1^{\mathrm{T}} \quad\left(=\mathrm{AS} \quad 2.4031^{\mathrm{T}}=\mathrm{CBS}\right.$ $11390^{\mathrm{T}}$ ), isolated from a piece of a decayed wood block of Pinus tabulaeformis Carr. from Lao Mountain in Shandong Province in the east of China in September 2008. 


\section{Acknowledgements}

This work is supported by the Director Innovation Foundation of Qingdao Institute of BioEnergy and Bioprocess Technology, Chinese Academy of Sciences.

\section{References}

Bai, F.-Y., Zhao, J.-H., Takashima, M., Jia, J.-H., Boekhout, T. \& Nakase, T. (2002). Reclassification of the Sporobolomyces roseus and Sporidiobolus pararoseus complexes, with the description of Sporobolomyces phaffii sp. nov. Int J Syst Evol Microbiol 52, 2309-2314.

Barnett, J. A., Payne, R. W. \& Yarrow, D. (2000). Yeasts: Characteristics and Identification, 3rd edn. Cambridge, UK: Cambridge University Press.

Fell, J. W., Boekhout, T., Fonseca, A., Scorzetti, G. \& StatzellTallman, A. (2000). Biodiversity and systematics of basidiomycetous yeasts as determined by large-subunit rDNA D1/D2 domain sequence analysis. Int J Syst Evol Microbiol 50, 1351-1371.

Hahn-Hägerdal, B., Karhumaa, K., Fonseca, C., Spencer-Martins, I. \& Gorwa-Grauslund, M. F. (2007). Towards industrial pentosefermenting yeast strains. Appl Microbiol Biotechnol 74, 937-953.

Kurtzman, C. P. (1998). Discussion of teleomorphic and anamorphic ascomycetous yeasts and a key to genera. In The Yeasts, a Taxonomic Study, 4th edn, pp. 111-121. Edited by C. P. Kurtzman \& J. W. Fell. Amsterdam: Elsevier.

Kurtzman, C. P. (2007). Eleven new species of Sugiyamaella and Candida from forest habitats. FEMS Yeast Res 7, 1046-1063.

Kurtzman, C. P. \& Robnett, C. J. (1998). Identification and phylogeny of ascomycetous yeasts from analysis of nuclear large subunit (26S) ribosomal DNA partial sequences. Antonie Van Leeuwenhoek 73, 331371.
Kurtzman, C. P., Robnett, C. J. \& Yarrow, D. (2001). Three new species of Candida from apple cider: C. anglica, C. cidri, and C. pomicola. Antonie Van Leeuwenhoek 80, 237-244.

Ladisch, M. R., Lin, K. W., Voloch, M. \& Tsao, G. T. (1983). Process considerations in the enzymatic hydrolysis of biomass. Enzyme Microb Technol 5, 82-102.

Makimura, K., Murayama, Y. S. \& Yamaguchi, H. (1994). Detection of a wide range of medically important fungi by the polymerase chain reaction. J Med Microbiol 40, 358-364.

Meyer, S. A., Payne, R. W. \& Yarrow, D. (1998). Candida Berkhout. In The Yeasts, a Taxonomic Study, 4th edn, pp. 454-573. Edited by C. P. Kurtzman \& J. W. Fell. Amsterdam: Elsevier.

Nakase, T. \& Suzuki, M. (1986). Bullera megalospora, a new species of yeast forming large ballistospores isolated from dead leaves of Oryza sativa, Miscanthus sinensis and Sasa sp. in Japan. J Gen Appl Microbiol 32, 225-240.

Suh, S. O., Marshall, C. J., McHugh, J. V. \& Blackwell, M. (2003). Wood ingestion by passalid beetles in the presence of xylosefermenting gut yeasts. Mol Ecol 12, 3137-3145.

Suh, S. O., White, M. M., Nguyen, N. H. \& Blackwell, M. (2004). The status and characterization of Enteroramus dimorphus: a xylosefermenting yeast attached to the gut of beetles. Mycologia 96, 756-760.

Suh, S. O., McHugh, J. V., Pollock, D. D. \& Blackwell, M. (2005). The beetle gut: a hyperdiverse source of novel yeasts. Mycol Res 109, 261265.

Wang, S.-A., Jia, J.-H. \& Bai, F.-Y. (2008). Candida alocasiicola sp. nov., Candida hainanensis sp. nov., Candida heveicola sp. nov. and Candida musiphila sp. nov., novel anamorphic, ascomycetous yeast species isolated from plants. Antonie Van Leeuwenhoek 94, 257-265.

Yarrow, D. (1998). Methods for the isolation, maintenance and identification of yeasts. In The Yeasts, a Taxonomic Study, 4th edn, pp. 77-100. Edited by C. P. Kurtzman \& J. W. Fell. Amsterdam: Elsevier. 